\title{
Tugas Menyalin Teks Dokkai untuk Meningkatkan Kemampuan Mahasiswa dalam Membaca dan Memahami Teks Berbahasa Jepang
}

\author{
1Yudi Suryadi, 2Diana Puspitasari \\ 1,2)Universitas Jenderal Soedirman \\ 1yudi.suryadi@unsoed.ac.id \\ 2diana.puspitasari@unsoed.ac.id
}

DOI: $10.18196 /$ jjlel.3229

\begin{abstract}
Abstrak
Penelitian ini bertujuan untuk mendeskripsikan hasil dari implementasi model penugasan menyalin teks pemahaman bacaan (dokkai) dalam mata kuliah Dokkai di Program Studi S1 Sastra Jepang FIB Unsoed dalam rangka untuk meningkatan kemampuan bahasa Jepang mahasiswa. Metode penelitian yang digunakan adalah metode penelitian tindakan (action research) dengan model penugasan menyalin teks dokkai sebagai perlakuannya (treatment). Subjek penelitian berjumlah 107 orang mahasiswa program studi S1 Sastra Jepang FIB Unsoed yang terdiri dari mahasiswa semester 4 angkatan 2017 dan semester 2 angkatan 2018. Pengumpulan data dilakukan dengan dua cara yaitu pemberian tes dan angket kepada mahasiswa. Data yang telah terkumpul kemudian dianalisis secara kuantitatif dan kualitatif sehingga dihasilkan suatu simpulan dari penelitian ini.

Berdasarkan hasil analisis data tes, diketahui bahwa mahasiswa semester 4 angkatan 2017 memperoleh nilai rata-rata 69, nilai tertinggi 96, dan nilai terendah 40, sedangkan mahasiswa semester 2 angkatan 2018 memperoleh nilai rata-rata 62, nilai tertinggi 94, dan nilai terendah 55. Selanjutnya, berdasarkan hasil angket tanggapan mahasiswa dapat disimpulkan bahwa 92,6\% mahasiswa setuju dengan model penugasan menyalin teks dokkai, karena dengan adanya tugas tersebut mahasiswa dapat lebih lancar membaca dan memahami isi teks yang telah dipelajari di kelas, dan sekaligus melatih mereka dalam membiasakan menulis huruf-huruf Jepang baik itu huruf Hiragana, Katakana, ataupun huruf Kanji.
\end{abstract}

Kata kunci: bahasa jepang, tugas menyalin, teks dokkai, action research 


\section{Abstract \\ (Title: An Assignment of Rewriting Dokkai Text to Improve Students 'Ability in Reading and Understanding Japanese Language Text)}

This study aims to describe the results of the implementation of the assignment model that is rewriting the dokkai text on the Dokkai course in the Japanese Literature Study Program of FIB UnSoed to improve students' Japanese language skills. This study used the action research method with the assignment of rewriting the dokkai text as its treatment. The research subjects were 107 students of the Japanese Literature Study Program of FIB UnSoed consisting of 4th-semester student class 2017 and 2nd-semester student class of 2018. The data collection used in two ways. They were giving tests and questionnaires to students. The data collected were then analyzed quantitatively and qualitatively to produce a conclusion from this study.

Based on the results of data analysis, the results of the test results for the 4th-semester student class 2017 got an average value of 69, the highest score of 96, and the lowest score of 40, while the 2nd-semester student class of 2018 got an average score of 62, the highest score of 94 , and the lowest value of 55. Furthermore, from the results of the questionnaire filled out by students, $92.6 \%$ of students agreed with the assignment model because of the assignment of rewriting the dokkai text. The students could more fluently read and understand the contents of the text studied in class. At the same time, it trained them to get used to writing Japanese characters, whether it was hiragana, katakana, or kanji.

Keywords: Japanese language; rewriting assignment; dokkai text; action research

\section{Pendahuluan}

Bahasa Jepang merupakan salah satu bahasa asing yang sekarang ini banyak dipelajari di Indonesia, baik itu di institusi formal seperti di perguruan tinggi ataupun nonformal seperti di tempat kursus. Pembelajaran bahasa Jepang tersebut umumnya bertujuan untuk melatih keterampilan berbahasa Jepang yang pada dasarnya dapat dibagi ke dalam empat keterampilan berbahasa (yon ginou), yaitu membaca (yomu koto), menulis (kaku koto), mendengar/menyimak (kiku koto), dan berbicara (hanasu koto).

Pada perguruan tinggi yang mempunyai program studi khusus bahasa Jepang seperti program studi S1 Sastra Jepang FIB Unsoed, empat keterampilan berbahasa tersebut dituangkan dalam satu paket mata kuliah wajib atau mata kuliah inti. Mata kuliah itu adalah mata kuliah tata bahasa (Bunpou), pemahaman bacaan (Dokkai), pemahaman dengaran (Choukai), penulisan karangan (Sakubun), dan percakapan (Kaiwa). Dari beberapa mata kuliah itu dapat dikategorikan menjadi dua kelompok, yaitu kelompok mata kuliah yang bertujuan melatih kemampuan reseptif seperti mata kuliah Dokkai dan Choukai, serta mata kuliah yang bertujuan melatih kemampuan produktif seperti mata 


\section{VOL. 3, NO. 2 AGUSTUS 2019

kuliah Sakubun dan Kaiwa. Untuk mata kuliah Bunpou bisa masuk ke dalam kategori mata kuliah reseptif maupun produktif karena mata kuliah ini merupakan dasar sebelum mengikuti mata kuliah Dokkai, Choukai, Sakubun, dan Kaiwa.

Dari beberapa mata kuliah tersebut, salah satu di antaranya yang sering menjadi titik lemah mahasiswa Sastra Jepang Unsoed adalah kemampuan Dokkai. Hal ini dapat dilihat dari data hasil ujian kemampuan bahasa Jepang (nihongo nouryoku shiken) mahasiswa Sastra Jepang Unsoed tahun 2016-2017 pada umumnya kurang nilainya dalam kemampuan Dokkai. Hal ini bisa terjadi dikarenakan apa yang mereka baca tidak bisa mereka pahami dengan baik sehingga terjadi kekeliruan dalam menjawab soal ujian. Selain itu, pada umumnya mahasiswa belum terbiasa dengan budaya membaca sehingga apabila pembelajaran Dokkai di kelas telah selesai, jarang sekali mahasiswa membaca kembali teks Dokkai yang telah dipelajarinya.

Oleh karena itu, dilakukanlah sebuah upaya untuk meningkatkan kemampuan Dokkai mahasiswa yaitu dengan sistem pemberian tugas menyalin teks Dokkai yang telah dipelajari di kelas. Dengan cara demikian, diharapkan mahasiswa menjadi terbiasa membaca teks berbahasa Jepang bahkan terbiasa menulis huruf Jepang, karena asumsinya bahwa dengan menulis berarti mahasiswa telah membaca. Untuk mengetahui hasil belajar mahasiswa dengan menggunakan model penugasan menyalin teks Dokkai dan tanggapan mahasiswa terhadap model penugasan tersebut diperlukanlah penelitian ini.

Penelitian ini bertujuan untuk mendeskripsikan hasil belajar mahasiswa dengan menggunakan model penugasan menyalin teks Dokkai agar dapat meningkatkan kemampuan mahasiswa dalam membaca dan memahami teks berbahasa Jepang, serta untuk mendeskripsikan tanggapan para mahasiswa terhadap model penugasan ini sehingga hasilnya bisa dijadikan pertimbangan untuk keberlanjutan model penugasan tersebut.

Manfaat dari penelitian ini adalah memberikan referensi atau alternatif dalam sistem penugasan yang dapat terukur dalam suatu perkuliahan, dan juga memberikan kontribusi positif terhadap proses perkuliahan untuk meningkatkan kemampuan 
berbahasa Jepang mahasiswa. Beragam cara dalam memberikan penugasan sebagai bentuk tugas terstruktur dalam perkuliahan akan memberikan dampak positif pada kemajuan mahasiswa. Melalui sistem penugasan yang tepat dan sesuai akan dapat meningkatkan kompetensi mahasiswa dalam menguasai bahasa Jepang.

Kegiatan belajar mengajar bukan hanya sekedar berbicara di depan kelas tentang materi pembelajaran, namun suatu proses transfer informasi pengetahuan dari sesorang pengajar kepada yang diajar. Berhasil tidaknya seorang pengajar didasarkan pada peningkatan kemampuan anak didiknya. Untuk mencapai target dan tujuan dari pembelajaran maka muncul banyak teknik pengajaran. Salah satu teknik yang digunakan adalah teknik penugasan atau yang biasa dikenal sebagai resitasi. Resitasi berasal dari bahasa Inggris to cite yang artinya adalah mengutip, dimana peserta didik mengutip atau mengambil bagian-bagian tertentu dari pelajaran, lalu belajar sendiri dan berlatih sendiri (Yusuf dan Anwar, 1997).

Teknik penugasan berbeda dengan pemberian pekerjaan rumah (PR). Teknik penugasan memiliki ruang lingkup yang lebih luas. Apabila PR ditujukan untuk dikerjakan di rumah, penugasaan dapat dilakukan di mana saja. Lebih lanjut Soekartawi (1995:19) menjelaskan bahwa resitasi adalah suatu cara yang menyajikan bahan pelajaran dengan memberikan tugas kepada peserta didik untuk dipelajari dan kemudian dipertanggungjawabkan.

Menurut Mulyasa (2007:113) bahwa dalam teknik penugasan memiliki beberapa hal yang harus diperhatikan agar dapat berjalan efektif, yaitu:

- Tugas harus direncanakan secara jelas dan sistematis, terutama tujuan penugasan dan cara pengerjaannya.

- Tugas yang dberikan harus dapat dipahami peserta didik. Kapan dikerjakan, bagaimana cara pengerjaanya, batas waktu pengerjaan, waktu yang diperlukan, secara individu atau kelompok, dan lain-lain.

- Apabila tugas berupa tugas kelompok, perlu diupayakan agar seluruh anggota kelompok dapat terlibat secara aktif dalam proses penyelesaian tugas tersebut, terutama kalau tugas tersebut diselesaikan di luar kelas. 


\section{VOL. 3, NO. 2 AGUSTUS 2019}

- Pengajar mengontrol proses penyelesaian tugas yang dikerjakan oleh peserta didik.

- Penilaian secara proporsional terhadap tugas-tugas yang dikerjakan peserta didik. Penilaian tidak hanya menitikberatkan pada produk (ending), tetapi perlu dipertimbangkan pula bagaimana proses penyelesaian tugas tersebut.

Penelitian yang menggunakan teknik resitasi pernah diulas dalam jurnal Pendagogia oleh Suparti (2014) yang meneliti hasil belajar siswa kelas III dalam memahami konsep pecahan sederhana. Dalam hasil penelitiannya menunjukkan bahwa metode tersebut berpengaruh terhadap hasil belajar siswa sekaligus meningkatkan nilai rata-rata saat ujian.

Penelitian yang berhubungan dengan upaya peningkatan kemampuan membaca pemahaman bahasa Jepang (Dokkai) banyak diulas oleh peneliti dengan menggunakan metode yang beragam, di antaranya adalah Juangsih (2012) yang menggunakan pendekatan story telling dalam pembelajaran Dokkai di Universitas pendidikan Indonesia.

Trahutami (2017) mengangkat permasalahan yang kerap muncul dalam pembelajaran membaca (Dokkai) pada tingkat menengah (chuukyuu). Penguasaan huruf kanji dan kosakata yang terbatas menyebabkan susahnya dalam menerjemahkan sehingga kurang maksimal dalam memahami isi teks bacaan. Menurutnya agar menghasilkan hasil yang optimal dalam pembelajaran Dokkai seharusnya dintegrasikan dan diselaraskan dengan materi keterampilan berbahasa lainnya yaitu kaiwa, choukai, dan sakubun.

Rasiban dan Dianasari (2017) mengungkapkan bahwa kesulitan dalam pembelajaran Dokkai karena susahnya memahami bunpo, kanji, arti kosakata, dan makna kalimat sehingga dalam penelitiannya menerapkan metode peer reading dalam pembelajaran Dokkai. Hasil dari penelitiannya menunjukkan bahwa metode peer reading lebih efektif dibandingkan dengan metode konvesional.

Penelitian tentang korelasi kemampuan Dokkai Chuukyuu Kohan dengan hasil JLPT N3 pada mata uji Dokkai juga dijadikan penelitian dalam bentuk skripsi oleh Lisdariyati (2015). Dalam pengumpulan datanya menggunakan metode dokumentasi yang bertujuan 
untuk mengetahui data mahasiswa yang dijadikan sebagai responden penelitian, serta data dokumentasi nilai UAS pada mata kuliah Dokkai Chuukyuu Kohan dan Nouryoku Shiken N3 pada mata uji Dokkai.

Dari hasil penelusuran hasil penelitian yang telah dilakukan, banyak ditemukan penelitian tentang strategi, metode, dan teknik dalam mata kuliah pemahaman bacaaan (Dokkai), namun belum ditemukan metode atau model penugasaan berupa menyalin teks dalam pembelajaran Dokkai untuk meningkatkan kemampuan mahasiswa dalam membaca dan memahami teks berbahasa Jepang.

\section{Metode Penelitian}

Penelitian ini menggunakan metode penelitian tindakan atau dikenal dengan istilah action research (Alwasilah, 2011). Menurut Sutedi (2009:147-149) bahwasanya dalam penelitian tindakan dilakukan berkali-kali dalam beberapa siklus sehingga diperoleh suatu bentuk baru untuk memecahkan permasalahan. Adapun tahapan-tahapan yang ada dalam penelitian ini yaitu meliputi kegiatan perencanaan, pelaksanaan, dan pelaporan.

Subjek dalam penelitian ini adalah mahasiswa program studi S1 Sastra Jepang yang berjumlah 107 orang, yaitu 55 mahasiswa semester 2 angkatan 2018 dan 52 mahasiswa semester 4 angkatan 2017. Objek penelitiannya adalah kemampuan pemahaman bacaan (dokkai) mahasiswa setelah diberi tugas menyalin teks dokkai dan tanggapan mahasiswa terhadap tugas menyalin teks dokkai tersebut. Instrumen penelitian yang digunakan terdiri dari dua, yaitu tes dan non tes. Instrumen tes berupa tes tertulis dan tes lisan, sedangkan instrumen non tes berupa angket atau kuisioner melalui media Google Form.

Langkah-langkah kerja yang dilakukan dalam penelitian ini adalah sebagai berikut.

\section{Siklus I}

o Penyusunan Rancangan Tindakan. Pada tahap ini dilakukan identifikasi, perumusan masalah, pengkajian literatur, tindakan yang akan digunakan, dan analisis yang akan dihasilkan. Pada tahap ini ditentukan dalam 7 kali pertemuan (pertemuan 1-7) mahasiswa mengerjakan 7 kali tugas menyalin teks dokkai. Setiap pertemuan, mahasiswa diminta untuk menyalin kembali teks dokkai yang telah mereka pelajari di kelas dalam kertas polos berukuran A4, dan dikumpulkan secara kolektif pada hari 
Jumat minggu tersebut. Penilaian didasarkan pada ketepatan waktu mengumpulkan tugas, kerapian dalam menyain teks dokkai, dan kesesuaian dengan instruksi penugasan dari dosen pengampu.

- Pelaksanaan dan Observasi. Pada tahap ini dilakukan tindakan berdasarakan skenario yang telah disusun pada rancangan tindakan dan disertai dengan kegiatan observasi. Mahasiswa diberi instruksi untuk mengerjakan tugas menyalin teks dokkai dan dikumpulkan pada hari Jumat. Setelah tugas mahasiswa terkumpul, dilakukan pengamatan terhadap hasil tugas mahasiswa. Tugas yang telah terkumpul kemudian direkap dan diinformasikan kepada mahasiswa supaya dapat diketahui siapa saja yang sudah dan siapa yang belum mengumpulkan tugas. Selain itu, tugas yang belum sesuai instruksi dikembalikan lagi kepada mahasiswa yang bersangkutan untuk direvisi.

- Refleksi. Pada tahap ini dilakukan evaluasi terhadap pelaksanaan tindakan yang telah dilakukan dengan mengacu pada data yang telah dikumpulkan dari kegiatan penugasan menyalin teks dokkai. Dari hasil refleksi, diketahui bahwa permasalahan dan kekurangan yang masih tersisa adalah dalam hal ketepatan waktu pengumpulan tugas, dan kesesuaian dengan instruksi penugasan, sehingga perlu diberi perlakuan tambahan di siklus berikutnya.

\section{Siklus II}

- Penyusunan Rancangan Tindakan. Pada tahap ini hasil refleksi pada siklus I menjadi bahan acuan untuk menyusun rancangan tindakan II. Pada tahap ini ditentukan kembali dalam 7 kali pertemuan (pertemuan 8-14) mahasiswa mengerjakan 7 kali tugas menyalin dan ditambah dengan tugas menerjemahkan teks dokkai. Setiap pertemuan, mahasiswa diminta untuk menyalin dan menerjemahkan kembali teks dokkai yang telah mereka pelajari di kelas. Instruksi yang diberikan pada tahap ini sedikit berbeda, yaitu mahasiswa selain diminta untuk menyalin teks dokkai juga diminta untuk menuliskan terjemahannya di bagian belakang kertas tugas mahasiswa. 
- Pelaksanaan dan Observasi. Pada tahap ini dilakukan implementasi seluruh tindakan II yang telah dirancang sebelumnya. Mahasiswa diberi tugas kembali untuk menyalin dan menerjemahkan teks dokkai yang sudah dipelajari di kelas. Setelah tugas terkumpul kemudian direkap kembali untuk mengetahui siapa saja mahasiswa yang sudah dan belum mengumpulkan tugas. Di dalam tahap ini, mahasiswa yang sudah selesai mengerjakan tugas juga diminta untuk mengunggah tugasnya di grup Whatsapp untuk memotivasi mahasiswa yang belum mengumpulkan tugas. Setelah semua tugas terkumpul, dilakukanlah pengamatan ataupun observasi terhadap hasil tugas para mahasiswa dan juga penilaiannya.

- Refleksi. Pada tahap ini dievaluasi hasil dari pelaksanaan sehingga mendapatkan hasil akhir dari penelitian yang dilakukan. Pada tahap ini dilakukan tes terhadap mahasiswa, yaitu berupa tes lisan dan tes tulis. Tes lisan diberikan untuk mengukur kemampuan membaca mahasiswa, yaitu dengan cara mahasiswa diminta untuk membaca dengan cepat dan tepat teks yang telah disediakan selama 1 menit. Selanjutnya, tes tulis diberikan untuk mengukur kemampuan pemahaman bacaan mahasiswa, yaitu dengan cara memberikan pertanyaan-pertanyaan seputar teks secara tertulis. Setelah tes selesai, mahasiswa diminta untuk memberikan tanggapan tentang model penugasan menyalin teks dokkai melalui angket yang telah disediakan dalam Google Form.

Hasil tes yang berupa tes lisan dan tes tulis, serta hasil angket mahasiswa kemudian diklasifikasikan, dianalisis, dibahas, dan disimpulkan.

\section{Hasil dan Pembahasan}

Penelitian ini untuk mendeskripsikan hasil belajar mahasiswa dengan menggunakan model penugasan menyalin teks dokkai, dan mendeskripsikan tanggapan mahasiswa terhadap implementasi model penugasan tersebut. Apabila model penugasan menyalin teks dokkai memberikan dampak positif terhadap mahasiswa, maka model penugasan tersebut perlu untuk dilanjutkan dan dikembangkan dalam pembelajaran mata kuliah Dokkai semester yang akan datang.

Pada siklus I, selama 7 pertemuan yaitu pertemuan ke-1 sampai dengan pertemuan ke-7 mahasiswa diberikan tugas menyalin teks dokkai yang telah dipelajari bersama- 


\section{VOL. 3, NO. 2 \\ AGUSTUS 2019

sama di kelas, kemudian dikumpulkan secara kolektif pada hari Jumat minggu tersebut. Setelah semua tugas mahasiswa terkumpul, dilanjutkan dengan mengklasifiksikan tugas berdasarkan angkatan dan kelasnya masing-masing dengan diurutkan berdasarkan nomor induk mahasiswa. Lalu, masing-masing tugas dicek apakah sudah sesuai dengan instruksi yang diberikan atau belum, dan diamati pula hasil tulisannya apakah sesuai dengan teks atau ada perubahan. Selain itu, ketepatan dalam pengumpulan tugas juga menjadi salah satu unsur penilaian.

Hasilnya menunjukkan bahwa hampir 90\% mahasiswa mengumpulkan tugas menyalin teks dokkai, meskipun ada beberapa mahasiswa yang mengumpulkan tugas melewati batas waktu yang ditentukan. Dilihat dari tulisannya, masih banyak mahasiswa yang mengubah huruf Kanji ke dalam huruf Hiragana dengan alasan bahwa huruf Kanji tersebut belum mereka pelajari di mata kuliah penulisan huruf Kanji, dan juga ada beberapa orang yang menulis di kertas bergaris sehingga tidak sesuai dengan instruksi yang diberikan, dan harus mengulang tugasnya.

Di dalam siklus I masih terdapat beberapa kekurangan, sehingga dilanjutkan dengan siklus II selama 7 pertemuan yaitu pada pertemuan ke-8 sampai dengan pertemuan ke14. Di dalam siklus ini mahasiswa tidak hanya diberi tugas menyalin teks dokkai saja, tetapi juga ditambah dengan tugas menuliskan arti dari teks tersebut ke dalam bahasa Indonesia di bagian belakang kertas tugasnya. Lalu, setiap mahasiswa yang telah selesai mengerjakan tugasnya, diminta untuk mengunggah tugasnya ke dalam grup Whatsapp, sehingga dengan begitu dapat memotivasi mahasiswa lain yang belum mengumpulkan tugas. Dengan cara demikian, mahasiswa yang mengumpulkan tugas tepat waktu menjadi hampir 95\% dari keseluruhan jumlah mahasiswa angkatan 2017 dan 2018.

Setelah semua tahapan di siklus I dan II dilakukan, kemudian diakhiri dengan pemberian tes dan angket kepada mahsiswa. Tes terdiri dari tes lisan dan tes tertulis. Tes lisan untuk mengukur kemampuan membaca dilakukan dengan cara membaca teks dokkai selama 1 menit. Tes tertulis untuk mengukur kemampuan pemahaman bacaan dilakukan dengan cara menjawab pertanyaan seputar teks secara tertulis. Setelah itu, 
mahasiswa diminta untuk mengisi angket tanggapan mahasiswa terhadap model penugasan menyalin teks dokkai melalui aplikasi Google Form.

Berikut ini adalah statistik evaluasi hasil belajar mahasiswa selama satu semester dalam mata kuliah Dokkai setelah diberikan penugasan menyalin dan menerjemahkan teks dokkai yang telah dipelajari di kelas, serta pembahasan hasil tanggapan mahasiswa terhadap model penugasan tersebut.

\section{Hasil Ujian Mahasiswa Semester 4 dalam Mata Kuliah Dokkai IV}

Hasil ujian mahasiswa semester 4 angkatan 2017 dalam mata kuliah Dokkai IV dapat dilihat pada grafik berikut ini.

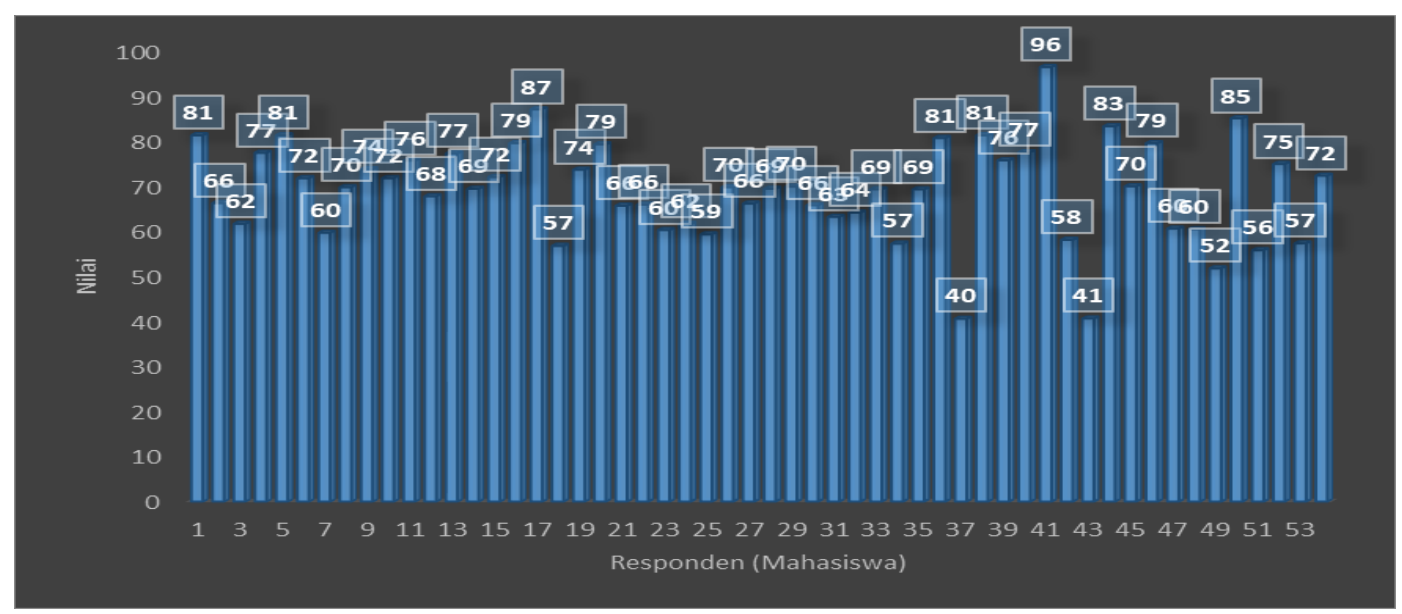

Gambar 1. Grafik Hasil Ujian Mata Kuliah Dokkai IV Mahasiswa Semester 4

Berdasarkan pada grafik tersebut, dapat diketahui bahwa nilai rata-rata mahasiswa dalam ujian mata kuliah Dokkai IV adalah 69 poin, nilai tertingginya 96 poin, dan nilai terendahnya 40 poin. Dari nilai rata-rata mahasiswa dapat dideskripsikan bahwa kemampuan mahasiswa semester 4 angkatan 2017 dalam mata kuliah Dokkai IV berada dalam kategori "lebih dari cukup", yaitu setara dengan nilai “BC" $(65,00-69,99)$.

\section{Hasil Ujian Mahasiswa Semester 2 dalam Mata Kuliah Dokkai II}

Hasil ujian mahasiswa semester 2 angkatan 2018 dalam mata kuliah Dokkai II dapat dilihat pada grafik berikut ini. 


\section{VOL. 3, NO. 2 AGUSTUS 2019}

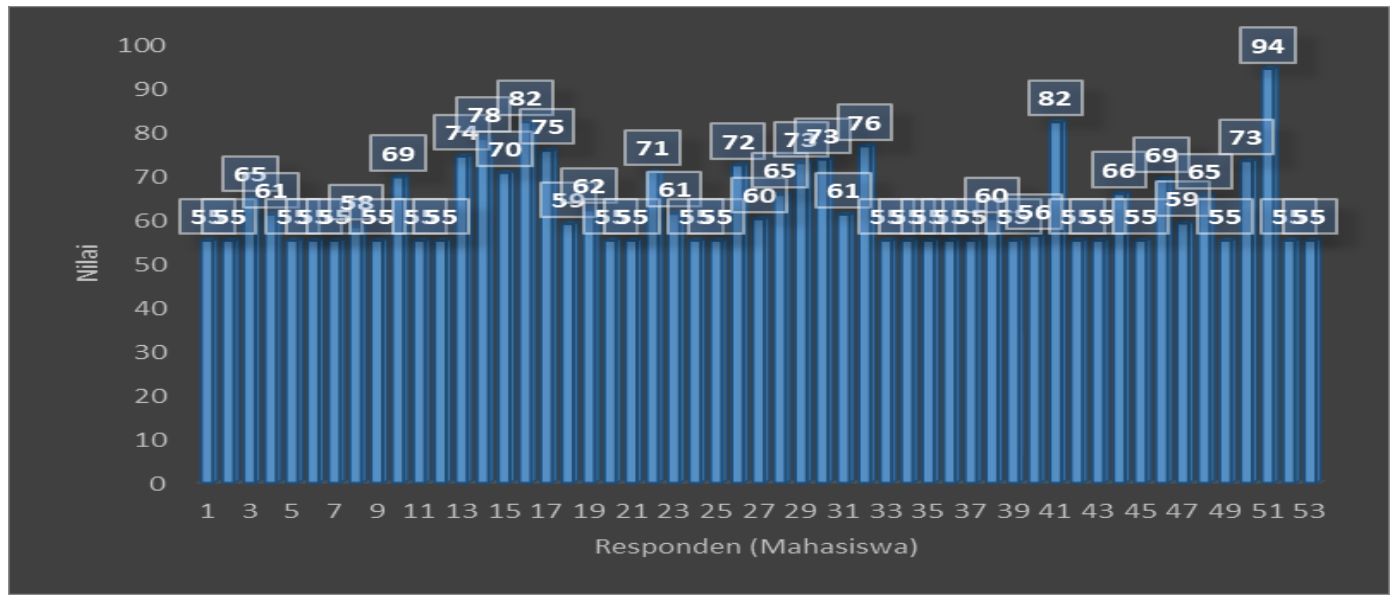

Gambar 2. Grafik Hasil Ujian Mata Kuliah Dokkai II Mahasiswa Semester 2

Berdasarkan pada grafik tersebut, dapat diketahui bahwa nilai rata-rata mahasiswa dalam ujian mata kuliah Dokkai II adalah 62 poin, nilai tertingginya 94 poin, dan nilai terendahnya 55 poin. Dari nilai rata-rata mahasiswa dapat dideskripsikan bahwa kemampuan mahasiswa semester 2 angkatan 2018 dalam mata kuliah Dokkai II berada dalam kategori "cukup", yaitu setara dengan nilai "C" $(60,00-64,99)$.

Dengan demikian, berdasarkan pada nilai hasil ujian mahasiswa semester 4 dalam mata kuliah Dokkai IV, dan semester 2 dalam mata kuliah Dokkai II, maka dapat disimpulkan bahwa kontribusi tugas menyalin teks dokkai dalam meningkatkan kemampuan pemahaman bacaan berbahasa Jepang mahasiswa masih belum optimal. Oleh karena itu, diperlukan upaya-upaya alternatif untuk lebih mengoptimalkan kemampuan berbahasa Jepang.

\section{Hasil Tanggapan Mahasiswa Terhadap Sistem Penugasan Menyalin Teks Dokkai}

Responden yang mengisi angket tanggapan berjumlah 107 orang yang terdiri dari 52 mahasiswa angkatan 2017, dan 55 mahasiswa angkatan 2018. Pertanyaan yang diberikan terdiri dari 12 pertanyaan yang berkaitan dengan sistem penugasan menyalin teks Dokkai. Hasil tanggapan mahasiswa terhadap pertanyaan-pertanyaan tersebut dapat digambarkan ke dalam beberapa diagram dalam tabel berikut ini. 


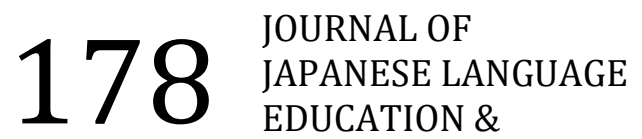 \\ LINGUISTICS}

1. Apakah tugas menyalin teks Dokkai membuat Anda lancar membaca teks berbahasa Jepang?

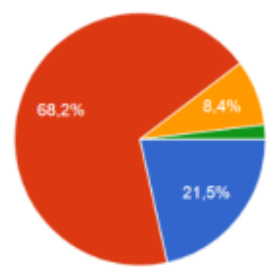

3. Apakah saat menyalin teks Dokkai Anda masih mengingat cara baca huruf kanji beserta artinya dalam teks tersebut?
2. Apakah tugas menyalin teks Dokkai membantu Anda memahami wacana yang dipelajari?

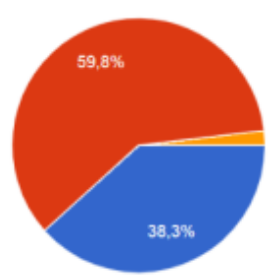

- Sanga

- Cukup

Kurang

- Tidak sama sekali

4. Apakah Anda setuju dengan sistem penugasan menyalin teks Dokkai tersebut?
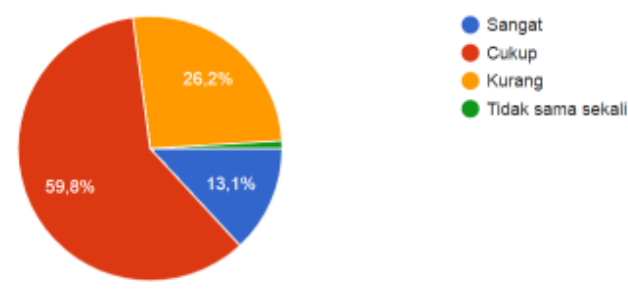

5. Apakah anda mengalami kesulitan ketika menyalin teks Dokkai?

6. Apakah Anda mengumpulkan tugas menyalin teks Dokkai tepat waktu?

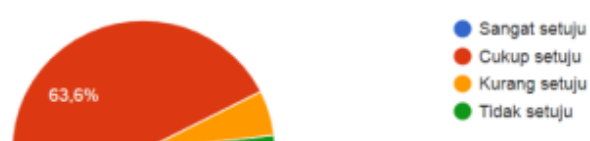

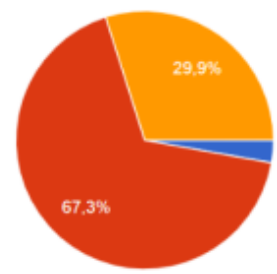

7. Di manakah Anda biasa mengerjakan tugas menyalin teks Dokkai?

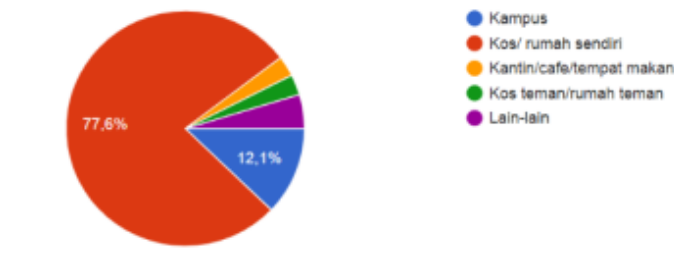

9. Apakah Anda memahami terjemahan/isi teks Dokkai yang Anda tulis?

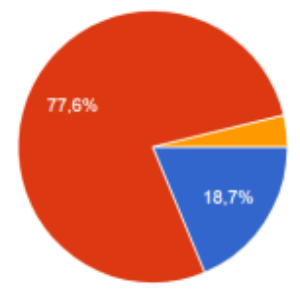
- Ya, sedikit kesulitan

Cukup

- Tidak sama sekal
Ya, banyak kesulitan - Tidak sama sekal

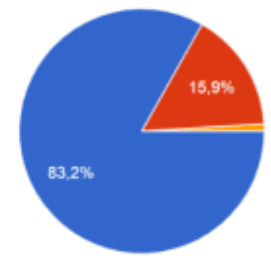

8. Apakah Anda mengerjakan sendiri tugas menyalin teks Dokkai?

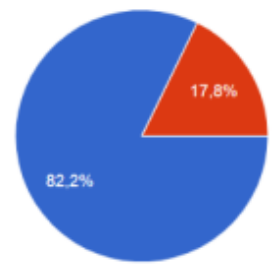

- Ya

Kadang-kadang

Tidak

10. Apakah Anda menerjemahkan sendiri teks Dokkai tersebut?

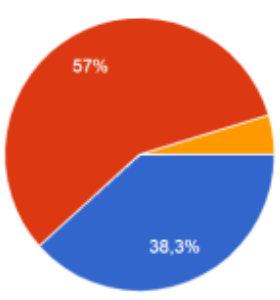

Ya

Kadang-kadang

Tidak 


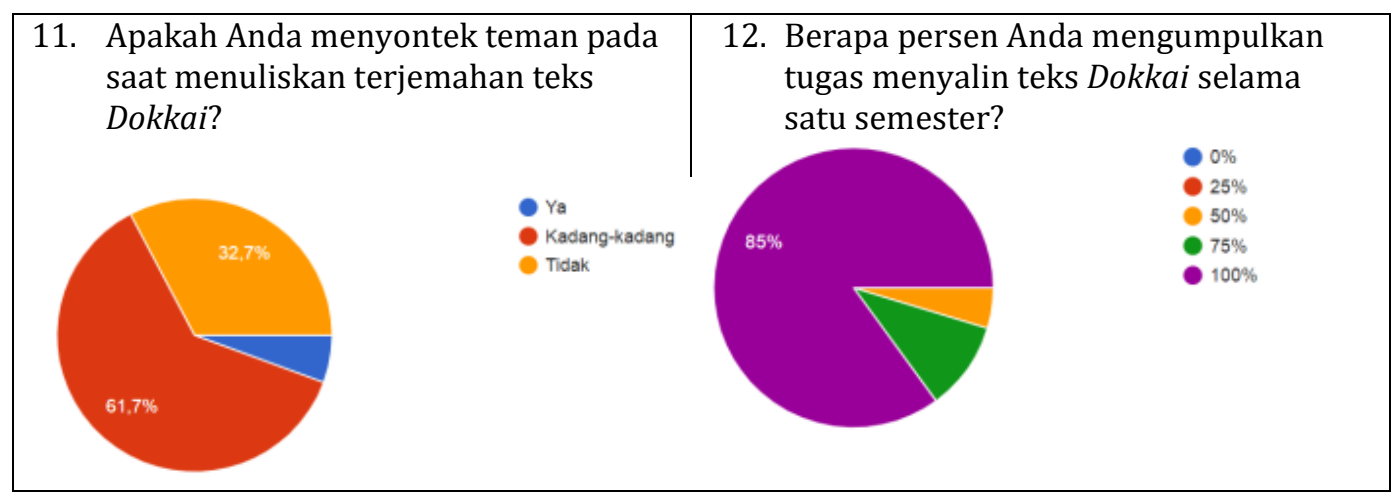

Tabel 1. Daftar Pertanyaan dan Diagram Hasil Tanggapan Responden

Berdasarkan hasil tanggapan mahasiswa dalam diagram tersebut terlihat bahwa pada umumnya para mahasiswa setuju dengan adanya sistem penugasan menyalin teks Dokkai, sehingga model penugasan ini dapat digunakan dan dikembangkan lagi di semester berikutnya. Secara keseluruhan, tugas menyalin Dokkai memberikan dampak positif bagi kemampuan membaca dan memahami mahasiswa, hanya saja karena masih banyak mahasiswa yang malas menerjemahkan arti teks secara mandiri sehingga kemampuan mahasiswa dalam memahami isi teks belum bisa mencapai target yang maksimal.

\section{Kesimpulan}

Berdasarkan hasil analisis data tes, dapat diketahui bahwa mahasiswa semester 4 angkatan 2017 memperoleh nilai rata-rata 69, nilai tertinggi 96, dan nilai terendah 40, sedangkan mahasiswa semester 2 angkatan 2018 memperoleh nilai rata-rata 62, nilai tertinggi 94, dan nilai terendah 55. Selanjutnya, berdasarkan hasil angket yang telah diisi oleh para mahasiswa dapat disimpulkan bahwa 92,6\% mahasiswa setuju dengan model penugasan tersebut, karena dengan adanya tugas menyalin teks dokkai, mahasiswa dapat lebih lancar membaca dan memahami isi teks yang telah dipelajari di kelas, dan sekaligus melatih mereka dalam membiasakan menulis huruf-huruf Jepang baik itu huruf hiragana, katakana, ataupun kanji.

Meskipun begitu, terkadang mahasiswa juga tidak semua rajin mengumpulkan tugas menyalin teks dokkai. Oleh karena itu, diperlukan upaya lebih lanjut untuk lebih 
memotivasi mahasiswa dalam mengerjakan dan mengumpulkan tugas mata kuliah Dokkai agar mereka dapat lebih meningkatkan kemampuan berbahasa Jepang, khususnya dalam hal pemahaman membaca (dokkai).

Penelitian ini masih dapat dikembangkan lagi dengan menggunakan pertanyaanpertanyaan lanjutan, seperti alasan kemalasan mahasiswa dalam mengerjakan tugas menyalin teks dokkai, kendala yang dihadapi mahasiswa, upaya yang dilakukan untuk mengatasi kendala tersebut, dan lain-lain. Selain itu juga terbuka kesempatan penelitian dengan rumusan permasalahan yang berbeda menggunakan data ini, seperti korelasi sistem penugasan menyalin teks dokkai dengan hasil evaluasi pembelajaran mata kuliah dokkai, dan sebagainya.

\section{Referensi}

Alwasilah, A. C.(2011). Pokoknya action research. Bandung: Kiblat.

Juangsih, J.(2012). Pendekatan story telling dalam pembelajaran dokkai: Penelitian terhadap mahasiswa jurusan pendidikan bahasa jepang. Jurnal Lingua Cultural. Vol. 6 No. 2 Hal. 183-187.

Lisdariyati.(2015). Korelasi kemampuan dokkai chuukyuu koohan dengan hasil nouryoku shiken $n 3$ mata uji dokkai. Universitas Negeri Semarang.

Mulyasa, E.(2007).Menjadi guru profesional menciptakan pembelajaran kreatif dan menyenangkan. Bandung: Rosdakarya.

Rasiban, L.M. \& Dianasari, W.(2017). Efektivitas metode peer reading dalam pembelajaran membaca pemahaman (dokkai)-the effectiveness of peer reading method in reading comprehension (dokkai) learning. Jurnal Japanedu. Vol. 2 no 1 hal 9-19.

Soekartawi.(1995). Meningkatkan efektivitas mengajar. Jakarta: PT Dunia Pustaka Jaya.

Suparti.(2014). Penggunaan metode penugasan atau resitasi untuk meningkatkan hasil belajar siswa kelas III dalam memahami konsep mengenal pecahan sederhana. Jurnal Pendagogia Vol 3 No. 1 Hal. 54-66.

Sutedi, D. (2009). Penelitian pendidikan bahasa jepang. Bandung: Humaniora.

Sutedi, D.(2019). Evaluasi pembelajaran bahasa jepang. Bandung: Humaniora.

Trahutami, S.I.(2017). Permasalahan pembelajaran Membaca Chuukyuu Dokkai di Perguruan Tinggi. Jurnal Kiryoku vol. 1 no. 4 hal. 48-54.

Yusuf, T. \& Anwar, S.(1997). Metode pengajaran agama dan bahasa arab. Bandung: PT Remaja Rosdakarya. 